\title{
A new species of poeciliid fish, Poeciliopsis santaelena, from Peninsula Santa Elena, Area de Conservación Guanacaste, Costa Rica
}

\author{
William A. Bussing \\ Escuela de Biología \& Centro de Investigaciones en Ciencias del Mar y Limnología (CIMAR), Universidad de Costa \\ Rica, Ciudad Universitaria, 2060 San José, Costa Rica; wbussing@biologia.ucr.ac.cr
}

Received 26-II-2007. Corrected 02-XII-2007. Accepted 31-I-2008.

\begin{abstract}
An undescribed freshwater fish was recently discovered during a biological inventory of Area de Conservación Guanacaste, northwestern Costa Rica. This new species of Poeciliopsis is closely related to a group of widespread species of small spotted fishes designated as the Poeciliopsis gracilis complex in this study. The complex extends on both versants from southern Mexico to Nicaragua, and with this new finding, extends into Costa Rica. The new species is distinguished from its Central American relatives by its lack of lateral and ventral markings, higher pectoral and caudal-fin counts and more posterior placement of the dorsal fin. Poeciliopsis santaelena is endemic to the Río Potrero Grande, a river whose flow is reduced to just a few pools during the long dry season and flows fully only during very rainy weather. It is just another in a growing list of threatened or endangered species found in this unique peninsular environment. Rev. Biol. Trop. 56 (2): 829-838. Epub 2008 June 30.
\end{abstract}

Key words: new endemic species, poeciliid fish, Santa Elena Peninsula.

In 1998 I identified several small fishes from Río Potrero Grande, Peninsula Santa Elena, Área de Conservación Guanacaste (ACG), Costa Rica (collection information in Janzen 1998), as Poeciliopsis gracilis, a widespread species known from southern Mexico to Nicaragua, although it lacked the typical midlateral spots of that species, and suggested that a larger series would be useful to determine whether the lack of any pigment pattern was truly typical of this population of Poeciliopsis. These specimens also were needed to provide additional mature male specimens for comparisons.

Two subsequent collections confirmed the lack of markings in this fish population, and provided enough material to compare with specimens of the $P$. gracilis complex from other sites in Central America. The results of the morphological comparison reveal that the Río Potrero Grande Poeciliopsis presents several consistent differences with populations north of Costa Rica and is herein recognized as a new species.

\section{MATERIALS AND METHODS}

Counts and measurements were made according to methods given by Hubbs and Lagler (1958). A short inconspicuous splint is counted as the first pectoral-fin ray. Body measurements are given in $\mathrm{mm}$ standard length (SL). All body proportions are in percent of SL. Vertebral numbers and structure of the gonopodial suspensorium were determined from cleared and alizarin-stained specimens. Nomenclature of head pores follows Gosline (1949). The holotype and 10 paratypes are deposited in the Natural History Museum of Los Angeles County (LACM); other paratypes and all comparative material is deposited in the Museo de Zoología, Universidad de Costa Rica (UCR). 


\section{RESULTS}

Poeciliopsis santaelena, new species Figures 1-4, Tables 1-4

Holotype. LACM 56480-1, mature male, $27.2 \mathrm{~mm} \mathrm{SL}$, partially isolated pool in Río Potrero Grande, approximately $8 \mathrm{~km}$ from river mouth, Sector Santa Elena, Area de Conservación Guanacaste, Guanacaste Province, 100 m elevation, February 22, 2006, collected by W. Bussing, M.M. Chavarría and D. Briceño (exUCR 2696-1).

Paratypes. UCR 2696-1, (41) 12.5-36.7 mm, same locality and data as holotype; UCR 2697-1, (4) 14.3-47.2 mm, Río Potrero Grande, pool draining into type locality, about $9 \mathrm{~km}$ from river mouth; UCR 2507-2, (3) 9.7-7.5 mm, Río Potrero Grande, February 10, 1998, collected by D. Janzen, A. Masis, M.M. Chavarría, O. Sandlund, et al.; UCR 2508-(1) 6, 17.2-28.5 mm,

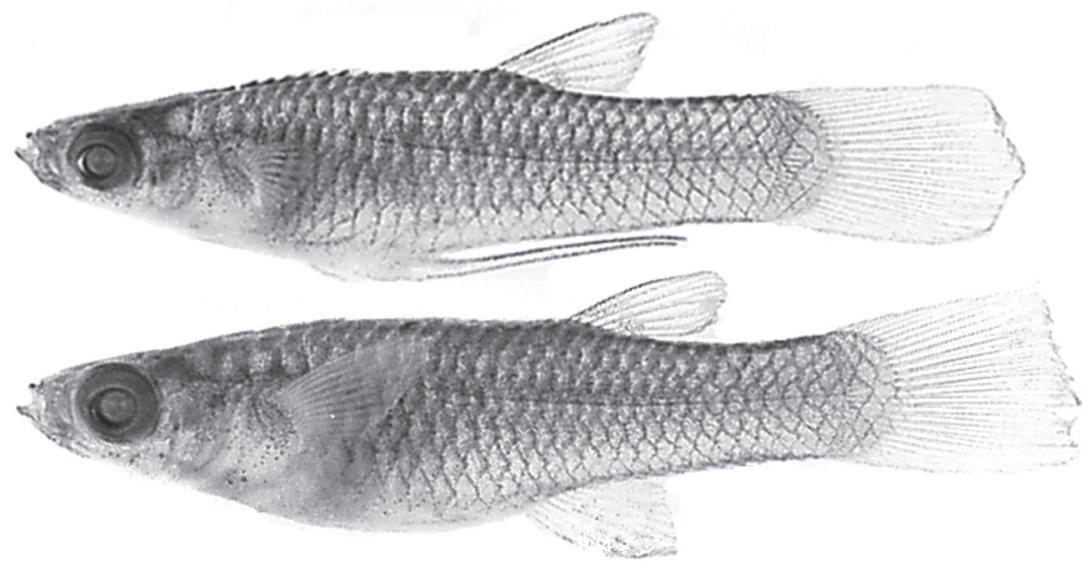

Fig. 1. Poeciliopsis santaelena, n. sp., UCR 2696-1, male paratype (upper) $21.5 \mathrm{~mm}$ SL, and female paratype UCR 2696-1, 25.5 mm SL, Río Potrero Grande, Costa Rica.

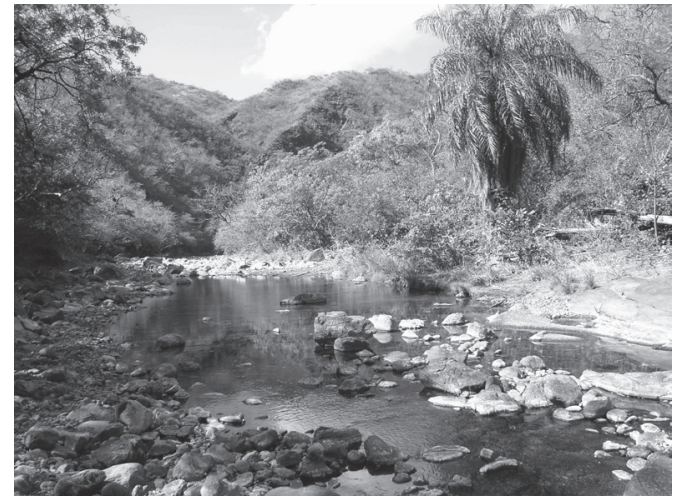

Fig. 2. Río Potrero Grande, one of several partially isolated pools during the dry season, February 22, 2006.
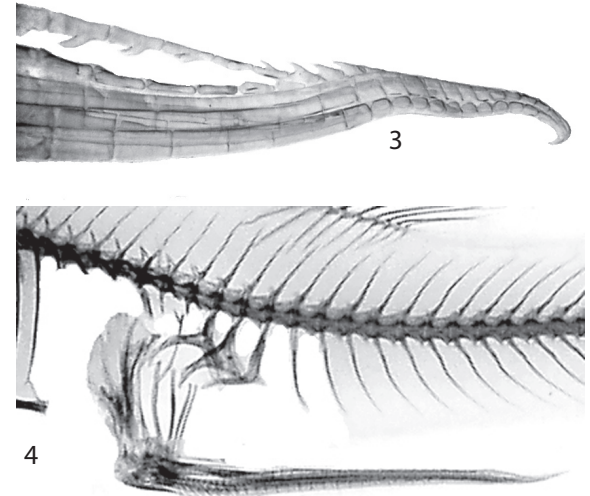

Fig. 3. Poeciliopsis santaelena, n. sp., UCR 2618-1, gonopodium of male paratype $24.3 \mathrm{~mm}$ SL, Río Potrero Grande, Costa Rica.

Fig. 4. Poeciliopsis santaelena, n. sp., UCR 2618-1, gonopodial suspensorium of male paratype $24.5 \mathrm{~mm} \mathrm{SL}$, Río Potrero Grande, Costa Rica. 
TABLE 1

Body proportions for Costa Rican specimens of Poeciliopsis santaelena and P. pleurospilus in percent of standard length

Poeciliopsis santaelena

Measurement

Standard length (mm)

Head length

Head width

Interorbital distance

Postorbital distance

Orbit length

Snout length

Body depth

Caudal peduncle depth

Predorsal distance

Preanal distance

Dorsal origin to $\mathrm{C}$ base

Anal origin to caudal base

Dorsal-fin length

Anal-fin/gonop. length

Pectoral-fin length

Pelvic-fin length

$\begin{array}{cc}\text { Holotype } & 10 \text { males } \\ 27.2 & 21.5-24,9 \\ 26.5 & 26.1-28.3 \\ 18.4 & 17.4-20.0 \\ 11.0 & 12.0-12.9 \\ 10.3 & 9.4-12.1 \\ 10.7 & 9.6-11.2 \\ 8.8 & 8.0-9.7 \\ 27.2 & 28.5-30.8 \\ 18.0 & 16.8-19.6 \\ 60.3 & 61.8-64.3 \\ 49.6 & 48.4-55.4 \\ 37.5 & 38.2-41.3 \\ 53.3 & 55.4-58.4 \\ 23.9 & 23.2-25.3 \\ 39.3 & 38.0-47.4 \\ 22.1 & 19.1-26.7 \\ 12.9 & 12.4-15.1\end{array}$

10 females

Poeciliopsis pleurospilus

*Based on UCR 401-6, Lago Amatitlán, Guatemala.

TABLE 2

Frequency distribution of distance from dorsal fin origin to caudal base in male Poeciliopsis santaelena and $\mathrm{P}$. pleurospilus in percent of standard length

\begin{tabular}{rrrrrrrrr}
\multicolumn{7}{c}{ Class Intervals } \\
37.0 & 38.0 & 39.0 & 40.0 & 41.0 & 42.0 & 43.0 & 44.0 & 45.0 \\
37.9 & 38.9 & 39.9 & 40.9 & 41.9 & 42.9 & 43.9 & 44.9 & 45.9
\end{tabular}

P. pleurospilus

Guatemala

El Salvador

Nicaragua (Pac.)

Nicaragua (Atl.)

P. santaelena

2

1
1

26.7-47.3

10 males*

10 females*

26.9-29.6

24.0-32.0

34.8-45.7

16.7-20.6

24.1-26.7

23.2-26.2

12.7-14.3

$.6-18.8$

17.7-21.3

11.2-12.3

'11.8-12.5

12.5-13.8

8.5-10.9

8.3-10.0

10.9-12.0

7.5-10.0

8.0-9.2

$7.5-8.6$

24.1-30.7

28.2-30.3

27.3-32.2

16.9-18.0

17.5-19.4

15.0-18.4

64.6-68.5

58.3-61.2

62.6-65.3

60.3-64.8

46.8-50.0

59.8-64.4

34.8-37.5

40.2-43.3

$37.0-40.8$

40.9-44.6

55.1-57.4

40.1-44.3

18.5-24.2

23.6-25.9

20.6-23.5

19.9-22.9

39.1-42.5

20.1-23.0

22.0-27.7

21.5-24.7

21.1-23.3

13.9-15.8

11.0-15.4

13.0-15.8 
TABLE 3

Frequency distribution of distance from dorsal fin origin to caudal base in female Poeciliopsis santaelena and $\mathrm{P}$. pleurospilus in percent of standard length

\begin{tabular}{lcccccccccc} 
& \multicolumn{8}{c}{ Class Intervals } \\
& 33.0 & 34.0 & 35.0 & 36.0 & 37.0 & 38.0 & 39.0 & 40.0 & 41.0 & 42.0 \\
& 33.9 & 34.9 & 35.9 & 36.9 & 37.9 & 38.9 & 39.9 & 40.9 & 41.9 & 42.9 \\
& & & & & & & & & & \\
$\begin{array}{l}\text { P. pleurospilus } \\
\text { Guatemala }\end{array}$ & & & & & 2 & 10 & 22 & 13 & 2 & 1 \\
El Salvador & & & & 1 & 4 & 4 & 1 & & & 1 \\
$\quad$ Nicaragua (Pac.) & & & & & 1 & & 1 & 5 & 1 & 1 \\
$\quad$ Nicaragua (Atl.) & & & & & 3 & 5 & 2 & & & \\
P. santaelena & 1 & 2 & 7 & 6 & 4 & & & & &
\end{tabular}

TABLE 4

Frequency distribution of the number of pectoral fin rays and caudal fin rays in Poeciliopsis santaelena and P. pleurospilus

Pectoral fin rays Caudal fin rays

$\begin{array}{lllllllllll}12 & 13 & 14 & 15 & 16 & 12 & 13 & 14 & 15 & 16 & 17\end{array}$

P. pleurospilus

Guatemala

El Salvador

Nicaragua(Pac.)

Nicaragua (Atl.)

P. santaelena

$\begin{array}{ll}3 & 102 \\ 1 & 37 \\ & 25 \\ 4 & 36\end{array}$

$15 \quad 94 \quad 25$

$\begin{array}{ccccc}1 & 2 & 52 & 26 & 6 \\ & 1 & 14 & 4 & 1 \\ & 4 & 8 & 2 & \\ 3 & 9 & 8 & & \\ & & & 14 & 40\end{array}$

10
Río Potrero Grande, February 10, 1998, collected by A. Masis, D. Janzen, M.M. Chavarría, R. Blanco, et al.; UCR 2618-1, (64) 20.8-39.1 $\mathrm{mm}$, Río Potrero Grande, about $11 \mathrm{~km}$ from mouth, 115 m elevation, March 19, 2003, collected by O. Sandlund, D. Janzen, et al.; LACM 56479-1, 5 males, 18.7-23.9 $\mathrm{mm}$ and 5 females, $27.6-36.0 \mathrm{~mm}$, same locality and data as UCR 2618-1.

Diagnosis. A species of Poeciliopsis, subgenus Poeciliopsis, with biserial dentition: teeth of outer row slender, pointed, curved and loosely implanted in lips. Total gill rakers 14 to 17 (mode
15). Dorsal-fin origin over $6^{\text {th }}$ or $7^{\text {th }}$ anal-fin ray of females; distance between dorsal-fin origin and caudal-fin base 33.0 to $37.5 \%$ of SL in females, 36.8 to $42.0 \%$ in males. Predorsal profile slightly curved. Mouth width less than eye diameter; interorbital width equal to or greater than postorbital distance. Pectoral fin in females reaching to middle of pelvic fin; pectoral fin rays 14 to 16 (mode 15 ). Caudal-fin rays 15 to 17 (mode 16). Color pattern gray above, paler below; cross-hatching conspicuous; no spots, bars or other markings; fins dusky or clear.

Description. A small, slender-bodied species of the genus. Predorsal profile slightly 
convex. Mouth terminal; mouth moderately wide, with very slight lateral cleft. Greatest depth at pelvic fin origin of females and at origin of gonopodium of males.

Fin rays (number of counts in parentheses; holotype count in bold font). dorsal, 7 (30); anal, 9 (10); pectoral 14 (15), 15 (94), 16 (25); pelvic, 6 (60); caudal, 15 (14), 16 (40), 17 (10). Scales: lateral series, 27 (2), 28 (6), 29 (11), 30 (1); predorsal, 14 (2), 15 (18); around caudal peduncle, 16 (10), 17 (10). Total gill rakers, 14 (4), 15 (8), 16 (5), 17 (1). Sensory canal pores: supraorbital 8 (20); preopercular, 6 (1), 7 (6), 8 (12), 9 (1); preorbital 2 (11), 3 (9); mandibular pores absent. Vertebrae: 30 (9), 29 (2); typically $11+19$.

Teeth in both jaws biserial. Outer row teeth pointed, very long and inwardly-curved; weakly implanted in jaws; outline indented medially. Teeth of inner row minute, barely discernable in gums and separated from outer row by a wide space covered with fine papillae. Intestines contained floculant organic detritus.

Gonopodium asymmetrical, sinistral, composed of anal rays 3, 4 and 5; tip with a small membranous hook (Fig. 3). Ray 3 thick proximally, longer than high, distal segments becoming square and progressively smaller at tip. Subdistal segments of posterior branch of ray 4 bearing thorn-like spines; two halves of posterior branch separated; 13-16 large unicuspid retrorse serrae on right half of ray 4 , diminishing in size anteriorly; 9 or 10 serrae on left half of ray 4, smaller anteriorly and a few bicuspid (two-horned processes) proximally. Segments of anterior branch of ray 5 squarish or rectangular, diminishing in size anteriorly and not entering into tip of gonopodium like rays 3 and 4 .

The gonopodial suspensorium, shown in Fig. 4 with last four ribs removed to reveal all structures, differs only slightly from those of other Poeciliopsis species (Rosen and Bailey, 1963). The gonapophyses branch ventrally with a long anterior arm and a shorter posterior arm. The anterior arm of gonapophysis 1 is longest and smoothly curved anteroventrally; the anterior arm of gonapophysis 2 is shorter and projected more ventrally; gonapophysis 3 is L-shaped, the anterior arm nearly horizontal. The posterior arms of gonapophyses 1 and 2 are robust and directed posteroventrally; the posterior arm of gonapophysis 3 is rudimentary.

Live coloration is gray becoming slightly paler below. Each scale is outlined by a dark border contrasting sharply with each pale silvery scale. A slender black subdermal median line extends from the anal to caudal fin base. Dorsal and caudal fin rays are dusky, other fins clear. No dark markings are present on head or body.

Habitat and associates. The Peninsula Santa Elena is a unique platform on which a unique biological community has developed, owing to its origin as an isolated oceanic island, extreme age, and serpentine soils. This community has been further molded by an extremely seasonal tropical climate - Santa Elena's weather regime is the driest place in Costa Rica. However, this unique community is also a damaged one that is now in a second stage of restoration following the past four centuries of European ranching, logging, road building, hunting and human-set fires (Janzen 1998).

The rainy season extends from the middle of May to late December. The Río Potero Grande arises about $350 \mathrm{~m}$ above sea level in a ravine on the southern slope of Cerros Santa Elena. The upper portion flows during the rainy season and then gradually diminishes as the dry season comes on. Several days of heavy daily rainfall lead to massive surface runoff and turn the dry ravines, stream beds and river beds into raging torrents that flow all the way to the Pacific Ocean. By the end of April, there is almost no flow and only isolated pools remain. Some large, shallow pools about 30-50 m long (maximum depth $60 \mathrm{~cm}$ ) are maintained by seepage and disappear underground about $6 \mathrm{~km}$ from the sea. In the type locality and adjoining pools the water was clear; some algal mats (Cladophora sp.) were present, otherwise only aufwuchs was present on the rocky substrata.

In addition to the shrimp Macrobrachium americanum and Atya innocuous, the following 
fish species were observed or collected in association with Poeciliopsis santaelena: Gobiomorus maculatus, Sicydium salvini, Agonostomus monticola and Eleotris picta.

Martin (1972) described the habitat of the related Poeciliopsis gracilis ( $=$ P. pleurospilus) in Honduras: "The habitat of this species is further characterized by extreme seasonality of flow varying from stagnation during the dry season to torrential flow during the wet season. Individuals were invariably captured in backwaters and isolated pools with little or no flow during dry season".

Etymology. The species is named for the Peninsula Santa Elena that contains the Río Potrero Grande, the only known locality of the new species.

Comparative material. Poeciliopsis pleurospilus (Günther, 1866)

Guatemala. Lago de Amatitlán, UCR 401-6, 130 specimens, $1186 \mathrm{~m}$ elevation (Fig. 5); Lago de Atitlán, UCR 402-1, 26 specimens, 1562 m elevation; Río María Lindo drainage, UCR 407-3, 25 specimens, $280 \mathrm{~m}$ elevation; UCR 408-4, 38 specimens, $100 \mathrm{~m}$ elevation; 410-2, 82 specimens, 400-620 m elevation; Río Michatoya, UCR 409-3, 16 specimens, 19-40 m elevation; Río Achiguate, UCR 411-2, 82 specimens, $40 \mathrm{~m}$.

El Salvador. Lago de Metapán, UCR 414-1, 27 specimens; Río El Lagartero, UCR 316-3, 25 specimens, 100 m elevation (Fig. 6).

Nicaragua Atlantic versant. Río near Yalaguina, 6 specimens, 700 m elevation; Río Malacatoya, UCR 265-2, 135 specimens, 100 m elevation.

Nicaragua Pacific versant. Río Tamarindo, UCR 273-5, 3 specimens, 40 m elevation; UCR 466-7, 11 specimens, $50 \mathrm{~m}$ elevation (Fig. 7); UCR 467-4, 5 specimens.

Remarks. A widespread species complex comprised of small, spotted poeciliids occurs on both versants from southern Mexico, continuing southward to Nicaragua, and with this description, terminating on the Pacific versant of Costa Rica. Rosen and Bailey (1963) noted that Poecilopsis gracilis was the earliest named member of the complex and included several other Mexican and Central American nominal species as synonyms ( $P$. pleurospilus, $P$. lutzi, and P. letonai). However, Miller (2004) in his book on Mexican fishes restricted the distribution of $P$. gracilis to Atlantic-slope streams including the Río Coatzacoalcos basin in Oaxaca, Mexico, as distinguished from the southern P. pleurospilus which he recognized as a valid species inhabiting both versants from southern Mexico to Honduras. Miller also mentions an undescribed sister species of gracilis in the Pacific-slope Río Verde drainage of Oaxaca. Poeciliopsis gracilis (Heckel, 1848) was originally described from the Orizaba Mountains, Atlantic-slope Veracruz, Mexico (Fig. 8); P. pleurospilus (Günther, 1866) from Lago de Dueñas, Pacific-slope Guatemala (Fig. 9); P. lutzi (Meek 1902, 1904) from Atlanticslope Río Quiotepec, Cuicatlán, Oaxaca, Mexico (Fig. 10) and P. letonai (Hildebrand 1925) from Río San Miguel, San Miguel, El Salvador (Fig. 11). Poeciliopsis catemaco Miller, 1975, found only in Laguna Catemaco, Veracruz, Mexico, is considered a semipelagic lacustrine derivative of $P$. gracilis. Günther (1868) described the Guatemalan P. pleurospilus with "... a black line along the base of the anal fin and the lower and upper margins of the tail. Caudal fin with two indistinct dark cross bands." None of our Guatemalan specimens have such caudal fin markings, which suggests that further studies are needed to clarify the valid name for members of the $P$. gracilis complex in Central America.

Heckel (1848) actually did not describe P. gracilis with a lateral series of dark spots. His description and figure depict a fish with a black longitudinal stripe extending from the angle of the opercle to the base of the caudal fin. Other pigmentation such as crosshatching was described as fins with black-brown margins: other fins were without markings. A black line extended between the anal and caudal fin bases. The gonopodium with hooked tip and other characteristics certainly suggest 


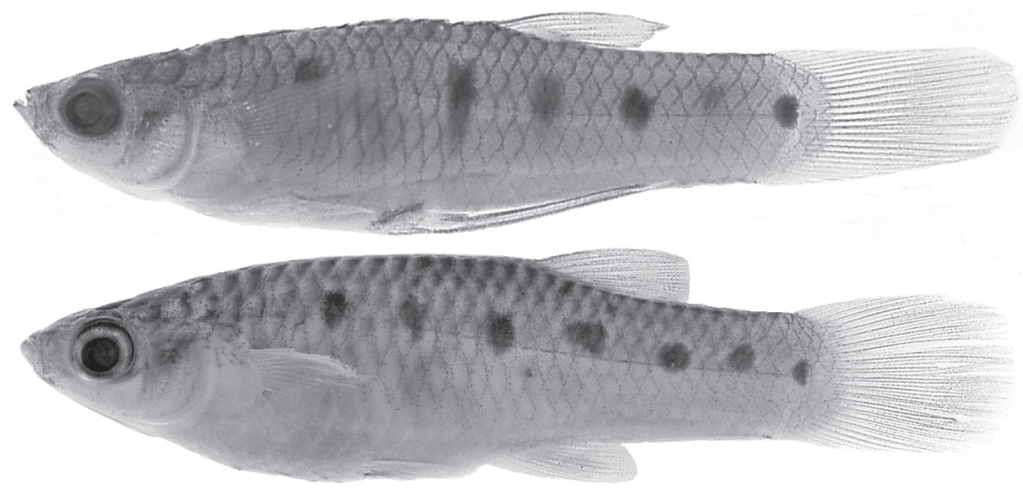

Fig. 5. Poeciliopsis pleurospilus. UCR 401-6, male (upper) $24.6 \mathrm{~mm}$ SL, female $35.2 \mathrm{~mm}$ SL, Lago de Amatitlán, Pacific slope Guatemala.

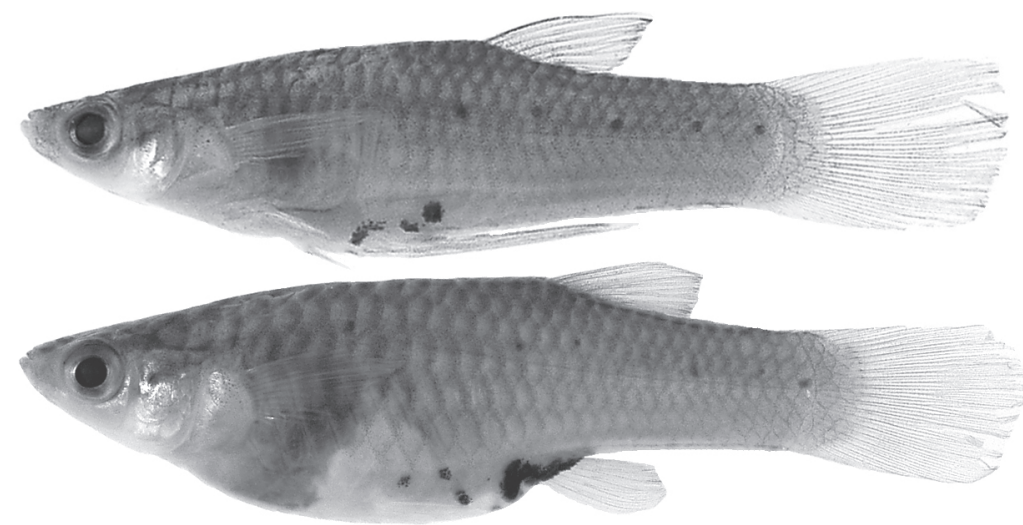

Fig. 6. Poeciliopsis pleurospilus. UCR 316-3, male (upper) $30.5 \mathrm{~mm} \mathrm{SL}$, female $40.4 \mathrm{~mm}$ SL, Río el Lagartero, El Salvador.

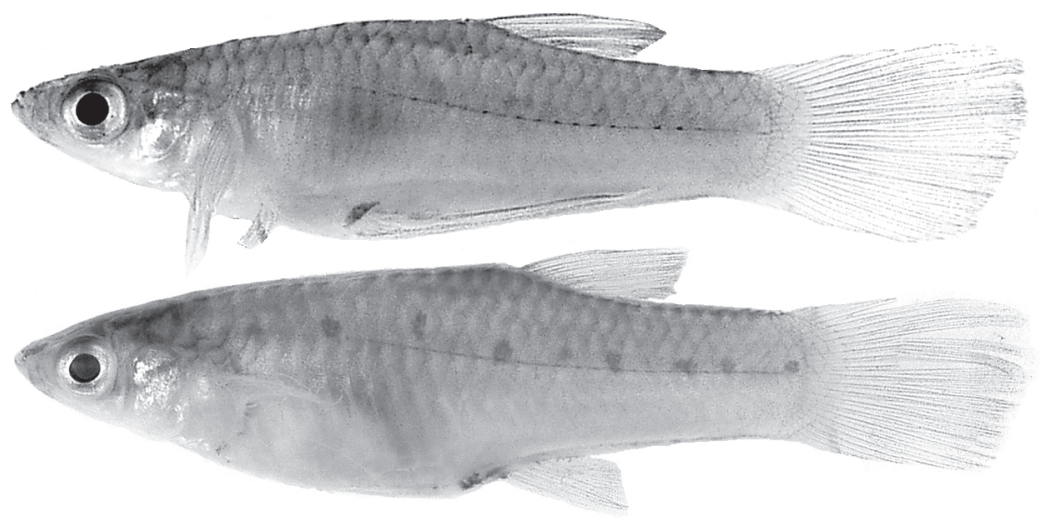

Fig. 7. Poeciliopsis pleurospilus, UCR 466-7, male (upper) $29.2 \mathrm{~mm} \mathrm{SL}$, female $35.2 \mathrm{~mm}$ SL, Río Tamarindo, Pacific slope Nicaragua. 


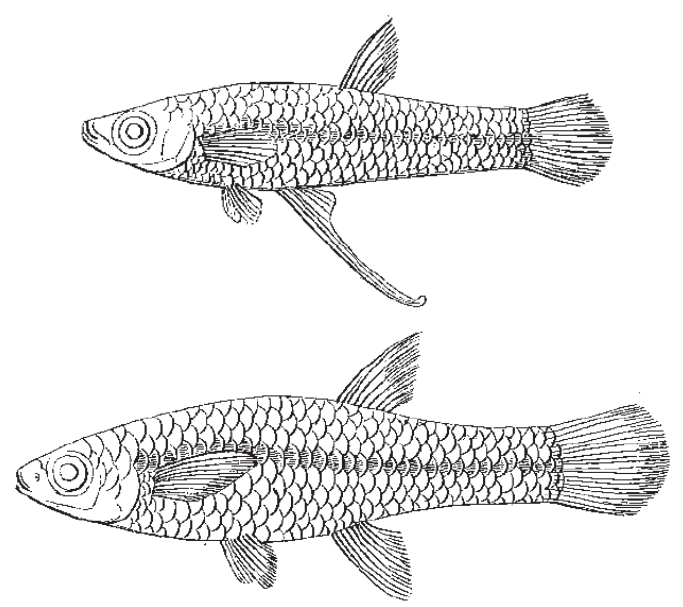

Fig. 8. Poeciliopsis gracilis, (Heckel, 1848), male syntype $33.4 \mathrm{~mm} \mathrm{SL}$, female syntype $44.0 \mathrm{~mm}$ SL from (Heckel, 1848: pl. 9, figs. 3,4), Orizaba Mountains, Veracruz, Atlantic slope Mexico.

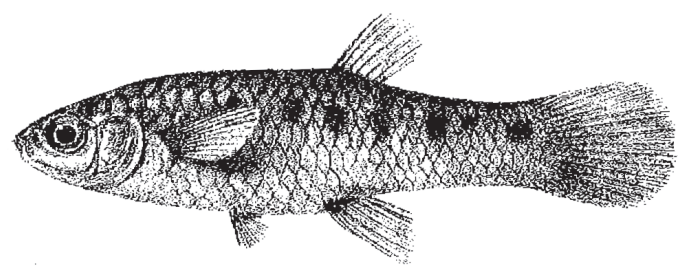

Fig. 9. Poeciliopsis pleurospilus (Günther, 1866) female syntype $43.0 \mathrm{~mm}$ SL from Günther (1868: pl. 87, fig. 1), Lago de Dueñas, Pacific slope Guatemala.

a species of Poeciliopsis, but the pigment pattern of this species from the Orizaba mountains differs from the figures of $P$. gracilis shown in Miller (2004).

Poeciliopsis santaelena is most closely related to and derived from P. pleurospilus of the $P$. gracilis complex. The Costa Rican species differs from pleurospilus in the following features (Tables 1-4): (1) more pectoral-fin rays, 14 to 16 (mode 15 ) vs. 12 to 15 (mode 13); (2) more caudal-fin rays, 15 to 17 (mode 16) vs. 12 to 16 (mode 14); (3) a more posterior dorsal fin, distance from dorsal fin origin to caudal base in males 37.5 to $41.3 \%$ vs 40.2 to $43.3 \%$, and in females 34.8 to $37.5 \%$ vs 37.0

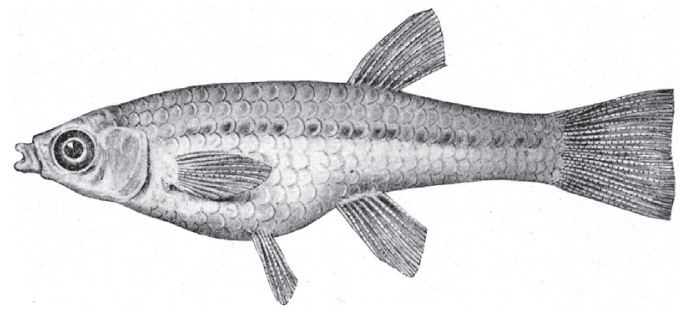

Fig. 10. Poeciliopsis lutzi (Meek, 1902), female syntype 9.2 mm SL, from Meek (1902: fig. 47), Río Quiotepec, Cuicatlán, Oaxaca, Atlantic slope Mexico.

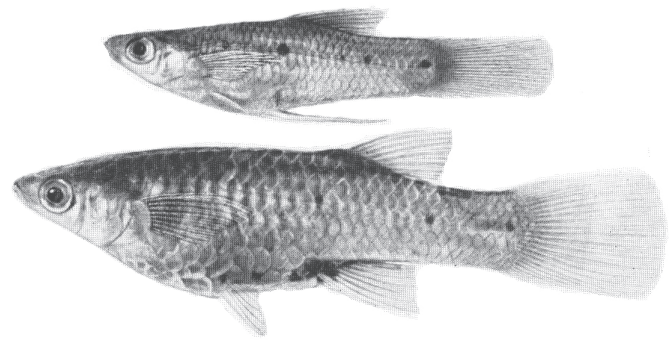

Fig. 11. Poeciliopsis letonai (Hildebrand, 1925), male holotype (upper) $42 \mathrm{~mm} \mathrm{SL}$, female $58 \mathrm{~mm} \mathrm{SL}$, from Hildebrand (1925: fig. 12), Río San Miguel, San Miguel, El Salvador.

to $40.8 \%$; (4) complete lack of dark midlateral spots vs 5-7 midlateral spots and scattered black ventral spots mostly concentrated around the origin of the anal fin of both sexes. Specimens of both sexes of $P$. pleurospilus typically bear a series of 5 to 7 midlateral spots. Specimens of $P$. pleurospilus reveal a clinal north to south variation from conspicuous midlateral spots equal to or larger than pupil size to often, faint dots smaller than the pupil; likewise the black ventral markings barely noticeable in some of the Guatemalan specimens, are conspicuous in individuals from El Salvador and Nicaragua (Figs. 5 \& 6). Specimens from Guatemala have large dark brown or black lateral spots 
and in some larger individuals the spots are vertically elongated (Fig. 5). Populations from El Salvador have quite small lateral spots, but jet-black ventral spotting is well developed (Fig. 6). Nicaraguan populations from both versants resemble each other, and also have very small lateral spots; some individuals lack nearly all lateral spotting, although ventral pigment is still evident. Specimens of $P$. santaelena lack both lateral and ventral spotting (the thin ventral anal to caudal line is present and shared with other species of the genus), nor do they present crossbars or other lateral markings as other Costa Rican Poeciliopsis such as $P$. turrubarensis, P. paucimaculata and P. elongata. Poeciliopsis retropinna, also an unmarked Costa Rican species, is distinguished from santaelena by its high number of total gill rakers (27-34) and other characteristics of members of the subgenus Aulophallus.

The gonopodium and gonopodial suspensorium of $P$. santaelena are essentially like that of our material of $P$. pleurospilus from Pacific slope Guatemala, El Salvador and both versants of Nicaragua. However the gonopodial suspensorium of "P. gracilis" from Pacific-slope Rio Tehuantepec, Oaxaca, Mexico (Rosen and Bailey 1963: Fig. 56B) is strikingly different from our Central American specimens of $P$. pleurospilus and perhaps represents a distinct species; the anterior arm of gonapophysis 2 is sharply directed ventrally at the tip and the posterior arm of gonapophyses 1 and 2 are bifurcated terminally. Clearly considerable more research is necessary to clarify the relationships of members of the $P$. gracilis complex.

Apparently $P$. santaelena represents an isolated relict population restricted to the south side of the Santa Elena Peninsula. Collections in streams on the north side of the peninsula (and the remainder of Costa Rica, Bussing 1998) revealed other species of poeciliids only: Poecilia gilli is common in such small streams and in the Rio Cuajiniquil; in the small Rio Cachimbo we found the wide-ranging Poeciliopsis turrubarensis. To the north, collections along the narrow Pacific slope of Nicaragua yield $P$. turrubarensis, Poecilia gilli and Poecilia sphenops. As far as we know, the Rio Tamarindo, near Puerto Somoza, Nicaragua is the southern limit of P. pleurospilus.

Conservation considerations. The lower portions of the major ravines leading down into the Rio Potrero Grande valley are all occupied by fragments of valley-bottom tall forests. These Santa Elena tall forests are the only back-beach mixed semi-evergreen dry forests being allowed to regenerate within a conserved wildland on the entire Pacific coast of Central America. The forests encircling Bahia Potrero Grande are one of the finest examples of this nearly extinct habitat (Janzen 1998).

Because Peninsula Santa Elena has fortunately been relatively isolated from deforestation during the past century (except for the fires continuing to whittle away at the dwarf forest on the uplands), and because it has not been generally available to subsistence farmer/ hunters, it still contains some amazingly intact populations of species that have been otherwise very severely threatened in Costa Rica. It also contains some remnants of very threatened species, remnants that are the seed for the restoration of these populations on a local basis. Finally, it contains an array of species that are very local (specialists to the soil, climate, age and insularity conditions of Santa Elena), or endemic (Janzen 1998).

The list of threatened or endangered species of plants and animals in the unique habitats of the ACG is already large and growing. Certainly Poeciliopsis santaelena, whose only habitat is a single stream in this dry and peninsular environment, merits being placed on this list.

\section{ACKNOWLEDGMENTS}

Thanks are due to the staff of the following Costa Rican offices: Area de Conservación Guanacaste (ACG), Sistema Nacional de Areas de Conservación (SINAC) of the Ministerio del Ambiente y Energía (MINAE). Biologist Roger Blanco, Research Coordinator for ACG, 
provided permits to conduct field work. I thank Daniel H. Janzen, Winnie Hallwachs, Alejandro Masis, Maria Marta Chavarría, Odd T. Sandlund, Roger Blanco and others who were the first to obtain fish collections from the Río Potrero Grande; and especially M.M. Chavarría and Duvalier Briceño whose expertise assured us of a successful 2006 field trip to the ACG and adjacent watersheds.

\section{RESUMEN}

Recientemente se descubrió una especie no descrita de pez dulceacuícola durante un inventario biológico en Area de Conservación Guanacaste (ACG) en el noroeste de Costa Rica. Esta especie nueva del género Poeciliopsis tiene un parentesco cercano con un grupo de especies con puntos en los costados ampliamente distribuidas que se designan en este informe como complejo de Poeciliopsis gracilis. El complejo se extiende en ambas vertientes desde el sur de México hasta Nicaragua. La especie nueva se distingue de sus parientes centroamericanos por su falta de manchas negras laterales y ventrales, mayor número de radios pectorales y caudales, y posición más posterior de la aleta dorsal. Poeciliopsis santaelena, especie endémica de un sólo riachuelo intermitente, es una especie más in la lista de especies en peligro que se encuentra en este peculiar ambiente peninsular.

\section{REFERENCES}

Bussing, W.A. 1998. Peces de las aguas continentales de Costa Rica. Editorial Universidad de Costa Rica, San José, Costa Rica. 468 p.

Gosline, W.A. 1949. The sensory canals of the head in some cyprinodont fishes, with particular reference to the genus Fundulus. Occas. Papers Mus. Zool. Univ. Michigan no. 519:1-17.

Günther, A. 1868. An account of the fishes of the States of Central America, based on collections made by Capt. J.M. Dow, F. Godman, Esq. and O. Salvin, Esq. Trans Zool. Soc. London 6: 377-494.

Heckel, J. 1848. Eine neue Gattung von Poecilien mit rochenartigen anklammerungs-Organe. Sitzber. K. Akad. Wiss. Wien, Math. Nat. Cl., 1: 289-303.

Hildebrand, S.F. 1925. Fishes of the Republic of El Salvador, Central America. Bull. Bur. Fisheries. 41: 237-287.

Hubbs, C.L. \& K.F. Lagler. 1958. Fishes of the Great Lakes region. Bull. Cranbrook Inst. Sci. 26: 1- 213 p.

Janzen, D. H. 1998. Conservation analysis of the Santa Elena property, Peninsula Santa Elena, northwestern Costa Rica. Report to the Government of Costa Rica, Area de Conservacion Guanacaste, ACG, Liberia, Guanacaste, Costa Rica, 129 pp. +4 Appendices.

Martin, M. 1972. A biogeographic analysis of the freshwater fishes of Honduras. Phd. Dissertation, University of Southern California, Los Angeles, California, USA. 598 p.

Meek, S.E. 1902. A contribution to the ichthyology of Mexico. Field Colombian Mus., Zool. Ser. 3: 63-128.

Meek, S.E. 1904. The freshwater fishes of Mexico north of the Isthmus of Tehuantepec. Field Colombian Mus., Zool. Ser. 5: 1-252.

Miller, R.R. 1975. Five new species of Mexican poeciliid fishes of the genera Poecilia, Gambusia, and Poeciliopsis. Occ. Papers Mus. Zool. Univ. Michigan No. 672: 1-44.

Miller, R.R. 2004. Freshwater fishes of Mexico. University of Chicago, Chicago, Illinois, USA. 464 p.

Rosen, D.E. \& R.M. Bailey. 1963. The poeciliid fishes (Cyprinodontiformes), their structure, zoogeography and systematics. Bull. American Mus. Nat. Hist.126: 1-176. 